\title{
Biodiversity priority areas and religions-a global analysis of spatial overlap
}

\author{
Grzegorz Mikusińsin, Hugh P. Possingham and Malgorzata Blicharska
}

\begin{abstract}
Numerous solutions have been proposed to slow the accelerating loss of biodiversity. Thinking about biodiversity conservation has not, however, been incorporated into the everyday activities of most individuals and nations. Conservation scientists need to refocus on strategies that reshape ethical attitudes to nature and encourage pro-environmental thinking and lifestyles. Religions are central to basic beliefs and ethics that influence people's behaviour and should be considered more seriously in biodiversity discourse. Using data from the World Religion Database we conducted an analysis of the spatial overlap between major global religions and seven templates for prioritizing biodiversity action. Our analysis indicated that the majority of these focal areas are situated in countries dominated by Christianity, and particularly the Roman Catholic denomination. Moreover, the Roman Catholic and Orthodox Churches appear to have the greatest per capita opportunity to influence discourse on biodiversity, notwithstanding the role of other religious communities in some key biodiversity areas.
\end{abstract}

Keywords Biodiversity templates, environmental attitudes, environmental ethics, religion

\section{Introduction}

Tn spite of various initiatives to halt the decline of biodiversity, extinctions are occurring at an increasing rate (Pimm et al., 1995; Stokstad, 2010). Biodiversity conservation has been recognized as an important global issue and there is general agreement that humanity is responsible for maintaining biodiversity for future generations (Mee et al., 2008). However, our failure to achieve the 2010 biodiversity target of the Convention on Biological Diversity (UN, 1992) for slowing the rate of biodiversity loss

GRZEGORZ MiKUSIŃSKI* Department of Ecology, Swedish University of Agricultural Sciences, Grimsö Wildlife Research Station, Riddarhyttan, Sweden

Hugh P. Possingham Australian Research Council Centre of Excellence for Environmental Decisions, School of Biological Sciences, University of Queensland, St Lucia, Australia

MalgorZata BlicharsKa (Corresponding author) Department of Aquatic Sciences and Assessment, Swedish University of Agricultural Sciences, Box 7050, SE-750 07 Uppsala, Sweden. E-mail malgorzata.blicharska@slu.se

* Also at: School for Forest Management, Swedish University of Agricultural Sciences, Skinnskatteberg, Sweden

Received 26 December 2011. Revision requested 13 February 2012.

Accepted 18 June 2012. First published online 28 August 2013. suggests that we need more effective ways to address conservation problems (Rands et al., 2010).

One traditional approach to biodiversity conservation has been top-down investment by governments and environmental NGOs. However, most governments have failed to stem the degradation of natural resources, including biodiversity (Acheson, 2006; Rockström et al., 2009). The inefficiency of these approaches has led to increasing interest in market-based approaches that place a monetary value on ecosystem goods and services, or achieve an outcome through mechanisms such as cap-and-trade (Rosales, 2006; Rands et al., 2010). Although science is seen as a source of the empirical knowledge on the functioning of ecosystems required to guide their management (Demeritt, 2001; Hobbs \& Harris, 2001), critics argue that the market-based approach has led to the exploitation of natural resources because of the agendas of governments, corporations and scientists: "mountains become 'natural resources', ancient forests are seen as 'agriculture', rivers of fish are 'stocks', and human communities become the "labour force" (Van Houtan, 2010). Although there are examples of successful actions by both top-down and market-based approaches to protect natural assets (Hepburn, 2007; Sodhi et al., 2011) both seem to be insufficient for slowing the rate of biodiversity loss. Hence there is a need for a complementary strategy to shape ethical attitudes and strive for more pro-environmental thinking and lifestyles amongst individuals and nations (Tilman, 2000; Van Houtan, 2006). Changed environmental attitudes and behaviour will in turn affect democratic governments, which ultimately reflect popular will in their actions.

One human dimension that has been neglected in the global biodiversity discourse is religious belief. The majority $(88.5 \%)$ of the world's population declare themselves as believers in some form of deity and as adherents of a religious community (WRD, 2010). Wilson (2006) stated: 'Religion and science are the two most powerful forces in the world today... If [they] could be united on the common ground of biological conservation, the problem would soon be solved'. By their definition, religions inherently aim to pursue moral good and have for centuries guided people with respect to what is right and what is wrong (Van Houtan, 2010). Moreover, religions are social traditions institutionalized by both their practices and moral narratives, which makes them legitimate in the social context.

Some scholars have argued that many religions, particular the Judeo-Christian tradition, are the root cause of all Western environmental problems, as they are inherently 
anti-nature (White, 1967; Toynbee, 1972). Lynn White's text has contributed to the myth among scientists of the anti-environmental nature of Christianity and Judaism (Van Houtan \& Pimm, 2006). However, this thesis is no longer widely accepted (Gardner \& Stern, 2002), notwithstanding the fact that there is an ongoing disagreement even within different religious groups on what their traditions are (Van Houtan \& Pimm, 2006). Some scholars have noted that the Christian Bible emphasizes stewardship of nature (Whitney, 1993; Worrel \& Appleby, 2000) and argue that religious leadership has the potential to support conservation (Boyd, 1984; Kanagy \& Willits, 1993; Bhagwat \& Palmer, 2009; Bhagwat et al. 2011a) provided that some values of conservation are embedded into the preaching of the mainstream faiths (Hall et al., 2009). Bhagwat et al. (2011b) examined the potential of religions in facilitating conservation of biodiversity and concluded that 'mainstream religions might provide an ethical perspective to many people in [biodiversity] hotspot countries'. Scientists have, for example, shown that designation of sacred places has played a key role in conservation (Hongmao et al., 2002; Bhagwat \& Rutte, 2006; Dudley et al., 2009).

As religions include basic beliefs and world-views as well as systems of ethics and morals (Gardner \& Stern, 2002) it seems reasonable to claim that they may influence people's behaviour. Therefore religions should be considered as a complementary force for the conservation of biodiversity and for related issues such as climate change, which has already been addressed from the religious perspective (Bergmann, 2009; Northcott, 2011).

Many scientists follow Gould's notion of distinguishing facts from morals (Gould, 1997) and are keen to keep strictly to their own domain (Van Houtan, 2006). However, conservation science and ethics are inextricably intertwined. On the one hand ethics are embedded in traditions formed by community-dependent practices sustained by both rituals and scientific argument (MacIntyre, 1981). On the other hand, conservation science is 'inescapably normative' (Barry \& Oelschlaeger, 1996) and is guided by the social context. Thus, religion may have important implications for successful practical conservation. However, as Van Houtan (2010) argues, the question is not about science and religion combining forces for practical conservation but about cultivating religious values, such as stewardship, for conservation.

Here, we present an analysis of which of the major religions may have the greatest opportunity to benefit conservation based on their spatial overlap with areas identified as the most important for terrestrial biodiversity conservation (Brooks et al., 2006).

\section{Methods}

Our analysis is based on three sources of global spatial information. Firstly, using the World Religion Database
(WRD, 2010) we extracted for every country in the world the percentage of people that are adherents of major global religions: Christianity (divided into four categories, Roman Catholic, Protestant, Orthodox, other Christian), Islam, Hinduism and Buddhism. The adherents of various other religions formed a separate category (other religions). Additionally, we extracted the percentage of people that are non-religious (agnostics and atheists). The second source of information was seven global biodiversity conservation priority templates in the form of geographical information system databases (Brooks et al., 2006). These are terrestrial biodiversity hotspots (Mittermeier et al., 2004), crisis ecoregions (Hoekstra et al., 2005), endemic bird areas (Stattersfield et al., 1998), megadiversity countries (Mittermeier et al., 1997), Global 200 ecoregions (G200; Olson \& Dinerstein, 1998), high-biodiversity wilderness areas (Mittermeier et al., 2003), and frontier forests (Bryant et al., 1997).

We overlaid these data on a digital political map of the world, using ArcView v. 3.3 (ESRI, Redlands, USA). Firstly, we calculated the area of each biodiversity template in each country and its percentage of total template area. For the template of megadiversity countries the overlay was not necessary because its polygons are countries. Secondly, we determined the spatial overlap of the individual templates with religion for particular countries, using the percentages of adherents of each religion in each country. This allowed us to link the religious profile of a particular country with the area of biodiversity templates located there. For example, the USA holds c. $4.2 \%$ of the area of the Global 200 ecoregions template. As $22.2 \%$ of its citizens are Roman Catholic, we calculated their 'area-share' of this template as $4.2 \times 22.2 / 100=0.93 \%$. In the next step, we summed 'area-shares' of individual biodiversity templates for all countries. Finally, taking into account the area covered by individual templates, the 'area-shares' of particular religions and the number of adherents of particular religions globally, we calculated how much area of an individual biodiversity template coincides with individual religions. To obtain a sense of the range of variation in 'area-shares' of biodiversity templates, we recalculated them per capita.

\section{Results}

The analysis shows unequal distribution of the adherents of the major religions in relation to the spatial location of the areas important for biodiversity. The continents, or their parts, that contain predominantly Christian countries also have the majority of areas with one or several priority areas for biodiversity (Fig. 1). Regionally, there is a large overlap of areas important for biodiversity with Buddhism (Southeast Asia), Hinduism (Indian subcontinent) and Islam (Asia Minor, parts of North and Central Africa). Countries with populations in the category 'other religions' and overlapping 
(a) Global religions

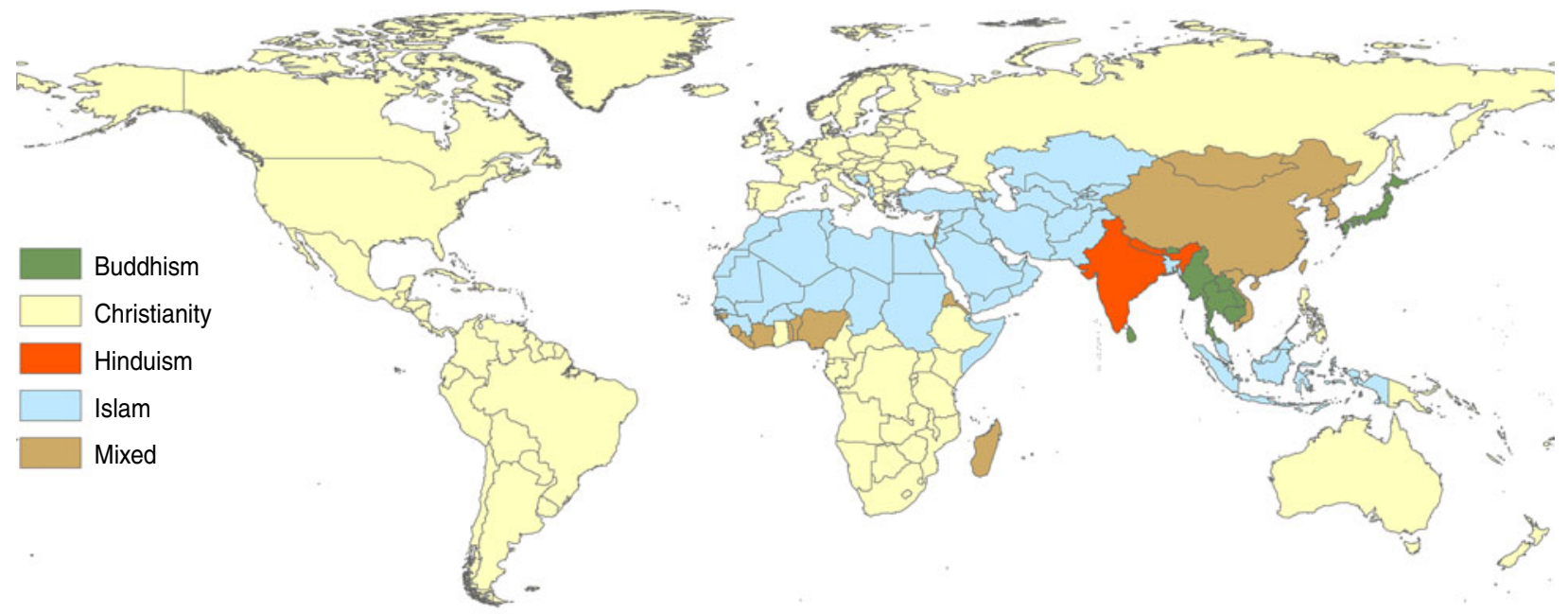

(b) Biodiversity templates

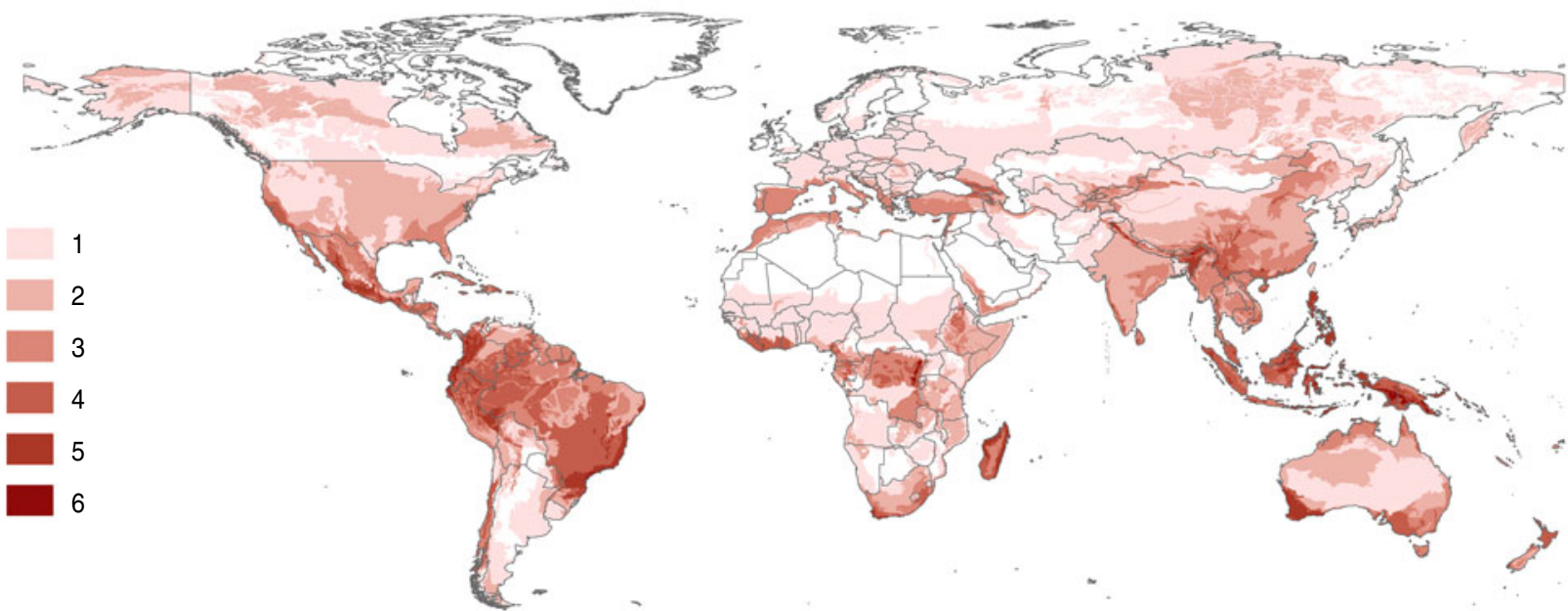

FIG. 1 (a) The dominance ( $\geq 50 \%$ ) of major global religions calculated at the country level, and (b) the distribution and spatial overlap of biodiversity templates (Table 1) used in the analysis (numbers and corresponding colour intensity indicate how many of the seven templates coincide spatially).

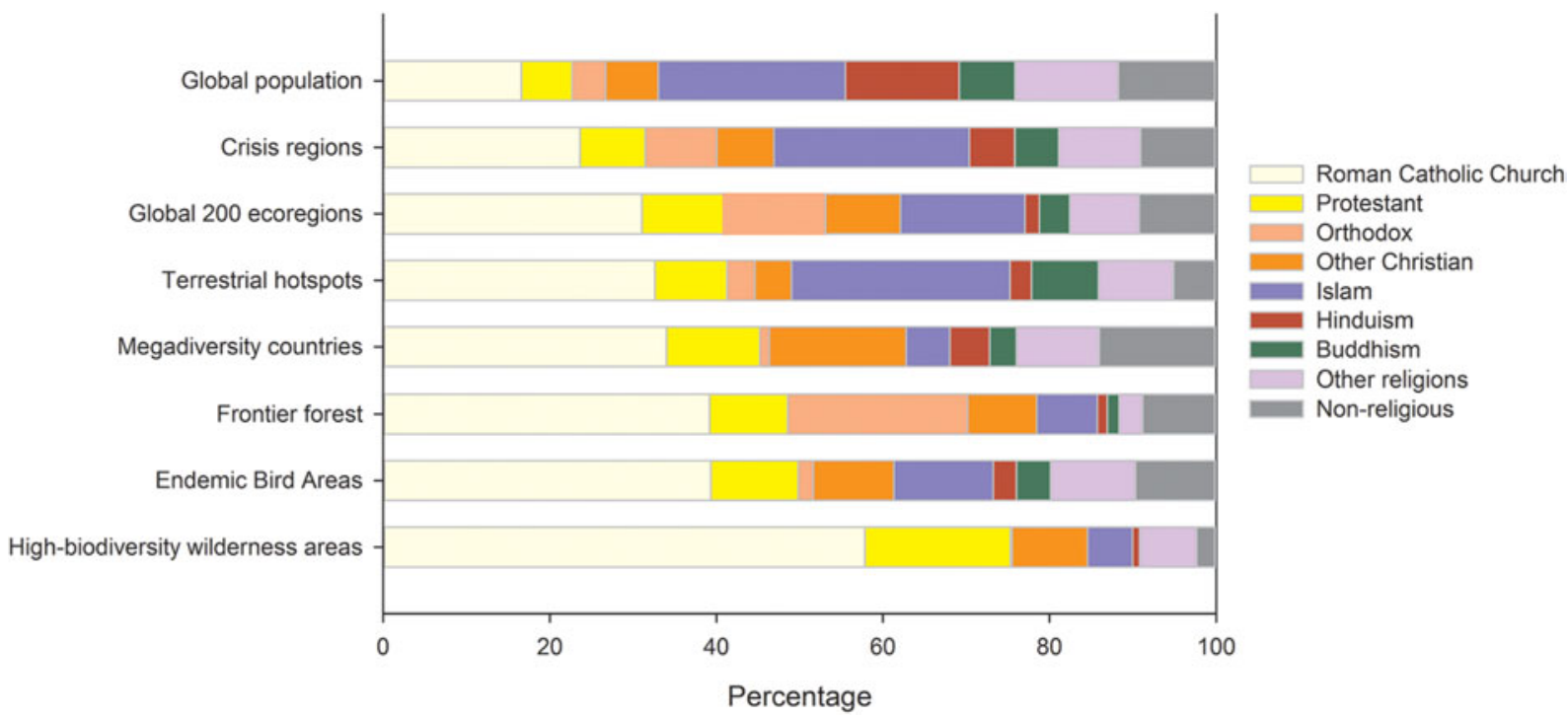

FIG. 2 The area-shares of global biodiversity conservation priority templates (Table 1) calculated for major religions, expressed as percentages. For comparison, the percentages of each religion amongst the global human population are provided in the top bar. 
TABLE 1 The areas of global biodiversity conservation templates that overlap with different religions, expressed as the number of hectares per capita human population. The highest figures in each template are in bold.

\begin{tabular}{llllllll}
\hline & $\begin{array}{l}\text { Crisis } \\
\text { regions }\end{array}$ & $\begin{array}{l}\text { Global 200 } \\
\text { ecoregions }\end{array}$ & $\begin{array}{l}\text { Terrestrial } \\
\text { hotspots }\end{array}$ & $\begin{array}{l}\text { Mega-diversity } \\
\text { countries }\end{array}$ & $\begin{array}{l}\text { Frontier } \\
\text { forest }\end{array}$ & $\begin{array}{l}\text { Endemic } \\
\text { bird areas }\end{array}$ & $\begin{array}{l}\text { High-biodiversity } \\
\text { wilderness areas }\end{array}$ \\
\hline Roman Catholic & 0.85 & 1.48 & $\mathbf{0 . 6 6}$ & 1.51 & 0.45 & $\mathbf{0 . 4 8}$ & $\mathbf{0 . 6 6}$ \\
Protestant & 0.77 & 1.27 & 0.48 & 1.36 & 0.30 & 0.35 & 0.54 \\
Orthodox & $\mathbf{1 . 2 9}$ & $\mathbf{2 . 4 4}$ & 0.28 & 0.20 & $\mathbf{1 . 0 4}$ & 0.09 & 0.01 \\
Other Christian & 0.65 & 1.12 & 0.23 & $\mathbf{1 . 9 1}$ & 0.25 & 0.31 & 0.27 \\
Islam & 0.62 & 0.53 & 0.39 & 0.17 & 0.06 & 0.11 & 0.05 \\
Hinduism & 0.24 & 0.10 & 0.06 & 0.26 & 0.02 & 0.04 & 0.01 \\
Buddhism & 0.47 & 0.43 & 0.41 & 0.35 & 0.04 & 0.12 & 0.00 \\
Other religions & 0.47 & 0.53 & 0.24 & 0.59 & 0.04 & 0.17 & 0.10 \\
Non-religious & 0.46 & 0.62 & 0.15 & 0.88 & 0.14 & 0.17 & 0.04 \\
\hline
\end{tabular}

with one or several biodiversity hotspots include Mongolia, Lao, Liberia (with a large proportion of religions classified as ethno religions), Madagascar (traditional religions) and China (folk religions).

The proportion of template areas overlapping with the distribution of Christians was higher than expected given their global population (Fig. 2). The spatial distribution of Roman Catholics had a particularly high degree of overlap with areas considered important for global biodiversity. For six of the seven templates the areas of biodiversity priority shared by predominantly Catholic populations were higher than expected given the proportion of Catholics globally. There was a similar but less pronounced pattern in the case of Protestants. The number of important areas for biodiversity shared by Hindus and other religions was lower than expected considering the number of adherents. The proportion of important biodiversity areas shared by adherents of Islam was comparable with the percentage of their global population in the case of two templates (crisis ecoregions and terrestrial biodiversity hotspots) but lower for the other templates.

The 'area-shares' of biodiversity templates by different religions, calculated per capita, are presented in Table 1. This analysis indicates that Roman Catholic and Orthodox Christian dominated areas have on average the highest biodiversity template area per capita (0.66-1.51 ha per capita for Roman Catholics and 0.01-2.44 ha per capita for Orthodox Christians). The Orthodox Church has proportionally the highest per capita area for three biodiversity templates: crisis regions, Global 200 ecoregions and frontier forests. This is because large areas of these templates are located in the Russian Federation, which has a high percentage $(79 \%)$ of Orthodox Christians. Similarly, the category 'other Christians' has proportionally the highest per capita area in the case of the megadiversity countries template because of the relatively low human population density in Australia and the USA, two large countries with a high proportion of Christians not linked to the Roman Catholic, major Protestant or Orthodox denominations.
The major factor driving this pattern is therefore human population density, which is usually low in countries dominated by Christianity (just over 20 persons $\mathrm{km}^{-2}$ on average), high in countries dominated by Buddhism $(>120$ persons $\mathrm{km}^{-2}$ on average) and very high in countries dominated by Hinduism ( $>300$ persons $\mathrm{km}^{-2}$ on average).

\section{Discussion}

Our analysis indicates that the majority of areas identified as the most important for global terrestrial biodiversity are situated in countries that are to a large degree dominated by Christianity, and more specifically Catholicism and Orthodoxy. This pattern is the result of a multitude of factors that we did not study, including the unequal distribution of biodiversity, the trajectory of the development of human societies in different parts of the world and their environmental footprint, and the way different religions have spread across the world. In addition, large countries dominated by Christianity have lower population densities and hence a generally greater fraction of any biodiversity template per person. Note that we do not claim that there is any causal relationship between the presence of areas important for biodiversity and particular religions.

We acknowledge that using data from the World Religion Database has its limitations. Firstly, the data provided on the country level are unable to take into account the issue of unequal spatial distribution of adherents of particular religions within a country. Secondly, some religious trends may not be apparent (e.g. people in Latin America turning towards apostolic and Pentecostal Christian denominations that are not institutionally organized and thus may not be reflected in the database). Other issues not included in our analysis include the different degrees of adherence, the power of various religions to influence the political process, and the role of religious leaders. Bearing in mind these limitations and also recognizing that our study indicates only a spatial relationship between different religions and the biodiversity templates, we treat our findings as a crude 
measure of the per capita conservation opportunity for each major religion.

The spatial resolution of our analysis is coarse and unequal because countries differ in area and religious adherence varies within countries. For example, a few large countries with relatively sparse human populations holding large areas of high biodiversity value (e.g. Canada, USA, Russia and Australia) weight results concerning some templates. Nevertheless, the governance of natural resources, including biodiversity, is to a large degree affected by the attitudes of all citizens (Rauschmayer et al., 2009) and conservation policies are in most cases implemented nationally (Knill \& Lenschow, 1998). Thus, we believe that our results may be useful to broaden the scope of the debate concerning the potential of religions to become involved in biodiversity conservation.

The debate on the role of religions in conservation is not new (e.g. Posey, 2000) and many religions have already been involved in some conservation action (Bhagwat \& Palmer, 2009; Mangunjaya, 2011). However, a greater involvement of religious communities in the conservation discourse, and a greater inclusion of conservation issues in religious ethics, could be beneficial for biodiversity. The fact that stewardship and conservation are closely related concepts offers hope for mutual progress. This potential should not be overlooked by the scientific community and other stakeholders seeking new ways to engage societies in conservation.

Amongst the various religions the Roman Catholic and Orthodox Churches have the greatest potential to support biodiversity conservation, as they are the dominant religions in areas important for global biodiversity. In the case of the Roman Catholic Church this potential may be assisted by the fact that it is centralized and thus moral guidance from its leaders could influence many people. Other religions are also important in the biodiversity conservation discourse, particularly within specific regions, such as Islam in Indonesia. A finer-scale analysis of the spatial distribution of religious adherents along with assessment of socio-ethical issues (e.g. the ability of a religion to influence political processes or the role of religious leaders in society) is needed to reveal the potential of religions in influencing proenvironment behaviour in areas of priority for biodiversity conservation. However, the practical issue is how to grasp the opportunity to involve religions in discourse about biodiversity conservation. We believe that the conservation community, including researchers, should be more active in finding good arguments to engage religions in biodiversity conservation. The results of our analysis may be one such argument.

\section{Acknowledgements}

We thank BirdLife International for their permission to use the EBA dataset, Kyle Van Houtan and an anonymous referee for constructive comments, Takuya Iwamura for his remarks on the topic of this paper and help with acquiring the data, and Kerry L. Nicholson for help with the figures. This study was funded by the Swedish University of Agricultural Sciences (GM and MB), the Australian Research Council, and the National Environmental Research Programme (HP).

\section{References}

ACHeson, J.M. (2006) Institutional failure in resource management. Annual Review of Anthropology, 35, 117-134.

BARRY, D. \& Oelschlaeger, M. (1996) A science for survival: values and conservation biology. Conservation Biology, 10, 905-911.

Bergmann, S. (2009) Religion in dangerous environmental change. IOP Conference Series: Earth and Environmental Science, 6, 572019 .

Bhagwat, S.A., Dudley, N. \& Harrop, S.R. (2011b) Religious following in biodiversity hotspots: challenges and opportunities for conservation and development. Conservation Letters, 4, 234-240.

Bhagwat, S.A., Ormsiy, A.A. \& Rutte, C. (2011a) The role of religion in linking conservation and development: challenges and opportunities. Journal for the Study of Religion, Nature and Culture, 5, 39-60.

Bhagwat, S.A. \& Palmer, M. (2009) Conservation: the world's religions can help. Nature, 461,37 .

Bhagwat, S.A. \& Rutte, C. (2006) Sacred groves: potential for biodiversity management. Frontiers in Ecology and the Environment, 4, 519-524.

Boyd, J.M. (1984) The role of religion in conservation. Environmentalist, 4, 40-44.

Brooks, T.M., Mittermeier, R.A., Da Fonseca, G.A.B., Gerlach, J., Hoffmann, M., Lamoreux, J.F. et al. (2006) Global biodiversity conservation priorities. Science, 313, 58-61.

Bryant, D., Nielsen, D. \& Tangley, L. (1997) The Last Frontier Forests: Ecosystems and Economies on the Edge. World Resources Institute, Washington, DC, USA.

Demeritt, D. (2001) The construction of global warming and the politics of science. Annals of the Association of American Geographers, 91, 307-337.

Dudley, N., Higgins-Zogib, L. \& Mansourian, S. (2009) The links between protected areas, faiths, and sacred natural sites. Conservation Biology, 23, 568-577.

Gardner, G.T. \& Stern, P.C. (2002) Environmental Problems and Human Behaviour, 2nd edition. Pearson Custom Publishing, Boston, USA.

Gould, S.J. (1997) Non-overlapping magisteria. Natural History, $106,16-24$

Hall, M., Grim, J. \& Tucker, M.E. (2009) Need for religions to promote values of conservation. Nature, 462,720 .

Hepburn, C. (2007) Carbon trading: a review of the Kyoto Mechanisms. Annual Review of Environment and Resources, 32, 375-393.

Hobbs, R.J. \& Harris, J.A. (2001) Restoration ecology: repairing the Earth's ecosystems in the new millennium. Restoration Ecology, 9, 239-246.

Hoekstra, J.M., Boucher, T.M., Ricketts, T.H. \& Roberts, C. (2005) Confronting a biome crisis: global disparities of habitat loss and protection. Ecology Letters, 8, 23-29.

Hongmao, L., Zaifu, X., Youkai, X. \& Jinxiu, W. (2002) Practice of conserving plant diversity through traditional beliefs: a case study 
in Xishuangbanna, southwest China. Biodiversity and Conservation, $11,705-713$.

KanaGy, C.L. \& Willits, F.K. (1993) A 'greening' of religion? some evidence from a Pennsylvania sample. Social Science Quarterly, $74,674-683$.

Knill, C. \& Lenschow, A. (1998) Coping with Europe: the impact of British and German administrations on the implementation of EU environmental policy. Journal of European Public Policy, 5, 595-614.

Macintyre, A. (1981) After Virtue. University of Notre Dame Press, Notre Dame, USA.

Mangunjaya, F.M. (2011) Developing environmental awareness and conservation through Islamic teaching. Journal of Islamic Studies, 22, 36-49.

Mee, L.D., Dublin, H.T. \& Eberhard, A.A. (2008) Evaluating the Global Environment Facility: a goodwill gesture or a serious attempt to deliver global benefits? Global Environmental Change, 18 800-810.

Mittermeier, R., Gil, P.R., Hoffmann, M., Pilgrim, J.D., Brooks, T.M., Mittermeier, C.G. et al. (2004) Hotspots Revisited: Earth's Biologically Richest and Most Endangered Terrestrial Ecoregions. Mexico CEMEX, with Conservation International, Agrupacion Sierra Madre, and University of Virginia, Monterrey, USA.

Mittermeier, R.A., Gil, P.R. \& Mittermeier, C.G. (1997) Megadiversity: Earth's Biologically Wealthiest Nations. Mexico CEMEX, Mexico City, Mexico.

Mittermeier, R.A., Mittermeier, C.G., Brooks, T.M., Pilgrim, J.D., Konstant, W.R., Da Fonseca, G.A.B. \& Kormos, C. (2003) Wilderness and biodiversity conservation. Proceedings of the National Academy of Sciences of the United States of America, 100, 10309-10313.

Northcott, M.S. (2011) Anthropogenic climate change, political liberalism and the communion of saints. Studies in Christian Ethics, $24,34-49$.

Olson, D.M. \& Dinerstein, E. (1998) The global 200: a representation approach to conserving the Earth's most biologically valuable ecoregions. Conservation Biology, 12, 502-515.

Pimm, S.L., Russel, G.J., Gittleman, J.L. \& Brooks, T.M. (1995) The future of biodiversity. Science, 269, 347-350.

Posey, D.A. (ed.) (2000) Cultural and Spiritual Values of Biodiversity. Intermediate Technology, London, UK.

Rands, M.R.W., Adams, W.M., Bennun, L., Butchart, S.H.M., Clements, A., Coomes, D. et al. (2010) Biodiversity conservation: challenges beyond 2010. Science, 329, 1298-1303.

Rauschmayer, F., Paavola, J. \& Wittmer, H. (2009) European governance of natural resources and participation in a multi-level context: an editorial. Environmental Policy and Governance, $19,141-147$.

Rockström, J., Steffen, W., Noone, K., Persson, Å., Chapin, F.S. III, LAmBin, R.F. et al. (2009) A safe operating space for humanity. Nature, 461, 472-475.
Rosales, J. (2006) Economic growth and biodiversity loss in an age of tradable permits. Conservation Biology, 20, 1042-1050.

Sodhi, N.S., Butler, R., Laurance, W.F. \& Gibson, L. (2011) Conservation successes at micro-, meso- and macroscales. Trends in Ecology and Evolution, 26, 585-594.

Stattersfield, A.J., Crosby, M.J., Long, A.J. \& Wege, D.C. (1998) Endemic Bird Areas of the World. BirdLife International, Cambridge, UK.

Stokstad, E. (2010) Despite progress biodiversity declines. Science, 329, 1272-1273.

Tilman, D. (2000) Causes, consequences and ethics of biodiversity. Nature, 405, 208-211.

Toynbee, A. (1972) The religious background of the present environmental crisis, a viewpoint. International Journal of Environmental Studies, 3, 141-146.

UN (1992) Convention on Biological Diversity. Concluded at Rio de Janeiro on 5 June 1992. United Nations Treaty Series No. 30619.

VAn Houtan, K.S. (2006) Conservation as virtue: a scientific and social process for conservation ethics. Conservation Biology, 20, 1367-1372.

Van Houtan, K.S. (2010) Conservation, biology, and religion. In Conservation Biology For All (eds N. Sodhi \& P.R. Ehrlich), p. 270. Oxford University Press, Oxford, UK.

Van Houtan, K.S. \& Pimm, S.L. (2006) The various Christian ethics of species conservation. In Religion and the New Ecology: Environmental Responsibility in a World in Flux (eds D.M. Lodge \& C. Hamlin), pp. 116-147. University of Notre Dame Press, Notre Dame, USA.

White, Jr, L. (1967) The historical roots of our ecologic crisis. Science, 155, $1203-1207$.

Whitney, E. (1993) Lynn White, ecotheology, and history. Environmental Ethics, 15, 151-169.

Wilson, E.O. (2006) The Creation: an Appeal to Save Life on Earth. Norton, New York, USA.

Worrel, R. \& Appleby, M.C. (2000) Stewardship of natural resources: definition, ethical and practical aspects. Journal of Agricultural and Environmental Ethics, 12, 263-277.

WRD (2010) World Religion Database. Http://www. worldreligiondatabase.org/wrd [accessed 9 May 2012].

\section{Biographical sketches}

GRZEGORZ MIKUSIŃSKI is interested in biodiversity conservation at different spatial scales, in Sweden and worldwide. His particular attention is directed towards forest environments and their bird fauna. Hugh Possingham is the director of two national research centres in environmental decision-making. He is interested in formulating and solving problems in nature conservation, using tools from applied mathematics, economics and statistics. MALGORZATA BLICHARSKA works with biodiversity policy implementation, public participation in environmental decision-making, conservation conflicts, ecosystem services and spatial planning for conservation. 